\title{
THE ANALYSIS OF CLASS MANAGEMENT ABILITY TO IMPROVE STUDENTS' ACTIVITY ON MATHEMATICS LEARNING PROCESS AT GRADE 8 SMP SWASTA PAB 2 HELVETIA
}

\author{
Nanda Tia Losi ${ }^{1 *}$, MY Siregar ${ }^{1}$ and Cici Puspaningrum ${ }^{1}$ \\ ${ }^{1}$ Pendidikan Matematika, Program Pascasarjana, Universitas Negeri Medan, Medan, Indonesia \\ *Email: nandatialosi@mhs.unimed.ac.id
}

\begin{abstract}
Abstrak: Dalam proses belajar mengajar, guru tidak hanya dituntut memiliki ilmu untuk diberikan kepada siswanya. Namun guru dituntut untuk memiliki kemampuan dalam mengelola kelas dengan baik. Penelitian ini bertujuan untuk menjelaskan aktivitas siswa dan pengelolaan kelas untuk mengatasi kesulitan belajar siswa pada pembelajaran Matematika. Penelitian ini menggunakan pendekatan kualitatif. Subjek penelitian adalah guru matematika dan siswa kelas 8 SMP PAB 2 Helvetia. Pengumpulan data dilakukan dengan observasi, wawancara, dan dokumentasi. Hasil penelitian menunjukkan bahwa sebagian besar guru mengelola kelas dengan baik, baik fisik maupun non fisik. Hal ini terlihat dari persentase sebagai berikut: (1) manajemen fisik 50\% dan manajemen non fisik 52,94\% (Guru G-1), (2) manajemen fisik 33,33\% dan manajemen non fisik 35,30\% (Guru G-2). Adapun aktivitas siswa kelas 8-1 dengan persentase sebagai berikut: (1) Kegiatan visual 66,22\%; (2) Kegiatan lisan 52,70\%; (3) Kegiatan mendengarkan 73,65\%; (4) Kegiatan menulis 73,65\%; (5) Kegiatan menggambar 0\%; (6) Aktivitas motorik 0\%; (7) Aktivitas mental 52,70\%; (8) Kegiatan emosional 54,05\%. Aktivitas siswa kelas 8-5 dengan persentase sebagai berikut: (1) Kegiatan visual 42,50\%; (2) Kegiatan lisan 30,63\%; (3) Kegiatan mendengarkan 41,25\%; (4) Kegiatan menulis 46,88\%; (5) Kegiatan menggambar 0\%; (6) Aktivitas motorik 0\%; (7) Aktivitas mental 33,75\%; (8) Kegiatan emosional $28,75 \%$.
\end{abstract}

Kata kunci: pengelolaan kelas, keaktifan siswa

Abstract: In the teaching and learning process, teacher is not only required to have knowledge to be given to his students. But teachers are required to have the ability to manage the class well. This research aimed to explain students' activity and the class management to overcome students' learning difficulty on Mathematics learning. This research used qualitative approach. The subject of research was the mathematic teachers and grade 8 students at SMP PAB 2 Helvetia. The data was collected by observation, interview, and documentation. The research result showed that mostly teachers managed the class well, physically and non-physically. It was seen by the following percentage: (1) physic management for $50 \%$ and non-physic management for $52.94 \%$ (Teacher of G-1), (2) physic management for $33.33 \%$ and non-physic management for $35.30 \%$ (Teacher of G-2).As for students' activity at grade 8-1by the following percentage: (1) Visual activities 66.22\%; (2) Oral activities 52.70\%; (3) Listening activities 73.65\%; (4) Writing activities 73.65\%; (5) Drawing activities 0\%; (6) Motor activities 0\%; (7) Mental activities $52.70 \%$; (8) Emotional activities $54.05 \%$. Students' activity at grade $8-5$ by the following percentage: (1) Visual activities 42.50\%; (2) Oral activities 30.63\%; (3) Listening activities 
41.25\%; (4) Writing activities 46.88\%; (5) Drawing activities 0\%; (6) Motor activities 0\%; (7) Mental activities 33.75\%; (8) Emotional activities $28.75 \%$.

Keywords: class management, students' activity

\section{INTRODUCTION}

Education is a right and also an obligation for every human. Education as a right is something that must be owned by every human, while education as an obligation is a responsibility that must be fulfilled by the human. It means that education is not a choice that can be chosen by the human to be accepted or denied, but education is a process that must be experienced by every human.

Mathematics is one kind of subject that is oriented on the process. Assumption spreading about the difficulty of learning Mathematics to the students make many teachers create shortcuts on the Mathematics learning process that causes omitting the concept of Mathematics itself. Mathematics studies about order and structure that is systematically organized because the process of Mathematics learning is the main key to actualize the purpose of Mathematics learning.

Syatra (2013:9) explained that the teaching and learning process is a process that contains a series of teacher and student actions or a reciprocal relationship that takes place in an educational situation to achieve a purpose. A teacher should look at everything that happens in the class to aid students to pass through the development steps. Through their job as a facilitator, the teacher tries to create an environment and provide the facilities that allow students to interact positively, actively, and creatively.

The teacher has various character to implement the education, one of them is to manage the class. The teacher is one of stakeholders to conduct class management. As a learning environment and a school aspect that need to be organized, the class must be changed by the teacher to be a better environment. Where, the good environment is the one which is challenging and to spur the students to study, gives the comfort, and warmth to achieve the education purpose.

To create a better teaching and learning situation, the teacher has to able to review and understand the basic concept of the class management, starts from the implemented approaches, the practice in the classroom that is continued by the analysis process. As the impact, the teacher will be able to manage the teaching and learning process more efficiently.

There is a relationship between the skills and techniques of effective classroom management on student academic achievement. What's more, the emotional relationship between teachers and students potentially enhance student achievement. One component of an effective classroom management is verbal and non-verbal skills. The skills can influence the behaviour of individual student and students in 
communal. The influence could be positive or negative depending on the behaviour of the teacher. (Prameswari, 2018: 80).

However, it is inversely proportional to SMP Swasta PAB 2 Helvetia. At the time of observation, the researcher found that the class was in a condition that was not conducive and not many students gave the interaction back to the teacher. Where the teacher still plays a major role in the delivery of learning material, this means, the interaction that occurs is still in one direction - between teacher and student, and does not get much response from students.

This is indicated by a positive response to the teacher's explanation, which only comes from the students who were sitting at the frontline. Meanwhile, most students who sit at the backline tend to do other activities, such as telling stories with their peers, doing activities outside the context of mathematics and being sleepy. This causes student activity to be distracted by other things. Then, this can also cause students' understanding of the subject matter to be uneven and low learning outcomes.

Looking at the description above, it is clear that classroom management by teachers played an important role in achieving educational goals. Class as a learning environment and aspects of the school that need to be organized, must be arranged and supervised so that learning activities are directed towards educational goals.

Although classroom management has an important position as described above, many aspects of classroom management are ignored by teachers. So that it has a negative impact on the learning process of students both in terms of learning motivation, decreasing in student discipline, and other things that are not expected. To create an atmosphere that can generate the passion for learning, improve the students' learning achievement, and enable the teachers to provide guidance and assistance to the students in learning, adequate class organization is needed.

According to Perangin Angin (2018: 7), class management is every attempt that is directed to implement an effective teaching and learning situation that is exciting and can motivate the students to learn well based on their ability.

Eferestson and Emmer (in Perangin angin, 2018: 6) stated that the class management is the teacher's attitude that produces a student involvement in the activity at class and decrease the students' attitude that disturb the teacher's time using or another student.

While according to Suherman and Nurjannah (2013: 18), class management is a realization to manage teaching and learning process systematically, that leads to learning material, facilities, and demonstration tool preparation, class setting, implement the situation/condition of teaching and learning process and time management, so that the teaching and learning process runs well and curriculum 
purpose can be achieved. Finally, if the class management runs well, the teacher will able to get the students achieve the purpose of Mathematics learning.

Based on the definition, the main point of class management purpose itself is to make a better teaching and learning process, active, directed, conducive, and exciting in order to achieve the effective and efficient learning purpose. Barnawi and Arifin $(2015 ; 153)$ explained that generally the class management purpose is to maintain the effective class organization.

Nurani (2020: 144) stated that there are some supporting factors in classroom management include: 1) Media and learning strategies, 2) Teacher-student relations, 3) Mastery of the material. While the inhibiting factors in class management are as follows: 1) the paradigm that mathematics is difficult, 2) the diverse character of the students, 3) The teacher is not good at class management. While the class management purpose specifically is: (1) to create and keep the optimal learning condition; (2) to return the optimal learning condition; (3) to realize the students' need, (4) to respond the students' attitude effectively; (5) to motivate students to be responsible to their attitude; (6) to build the students awareness to behave in order; and (7) to create the obligation to get involve in the class activity.

The main problem to manage class is the students themselves. Nagler (2016: 165) explained that it is possible the most difficult aspect of teaching for many beginning teachers is managing students' behaviour. The time a teacher has to take to correct misbehavior caused by poor classroom management skills results in a lower rate of academic engagement in the classroom. Effective classroom management involves clear communication of behavioural and academic expectations as well as a classroom environment conducive to learning.

It means that the class management is conducted to improve and maintain the students' motivation to study at class, both of in individual or group, and also helps the students to teach the learning material well and effectively. According to Rusydie (2015: 32), a class can be classified as well-managed if there is a harmonized relationship between the teacher and students, the high cooperation among students, and also keeps maintaining the students' enthusiasm to study the subject.

Moreover, it is needed the approaches to make a class to be well-managed. Based on the explanation above, Rusyide (2015: 52) explained that there are approaches in class management, they are: (1) authority approach; (2) threatening approach; (3) freedom approach; (4) receipt approach; (5) teaching approach; (6) attitude modification approach; (7) socio-emotional approach; (8) group process approach; (9) elective approach.

In the class management, it will face various of obstacles certainly. The act of class management by the teacher will be effective if the teacher can identify correctly the real problem that is faced, so on the time its coming, the teacher can choose the right strategy to overcome the problems. The first problem 
that happens in the class management is individual problem, Dreikurs and Cassel (in Rohani 2010: 145) distinguished four problem groups related to class management that is based on assumption that every individual's attitude is an attempt to achieve the purpose of decision fulfilment to be accepted by the group and the necessity to achieve pride, the attitude is classified as follow: (1) Attention getting behaviour's; (2) Power seeking behaviour's; (3) Revenge seeking behaviour's; (4) Hopelessness.

Meanwhile the second problem that happens in the class management is group problem. Johnson and Bany (in Rohani 2010: 146) claimed six categories of group problem in the class management, such as: (1) the class is less cohesive; (2) the class reacts negatively to one of the class members; (3) encourage the class member is considered as violating group norms; (4) the group is tending to be easy to distract from the project which is still on the progress; (5) less motivation; (6) the class is not able to adapt to the new one.

From the observations in class VIII SMP PAB 2 Helvetia during the learning process, it can be seen that the class is in a condition that is not conducive and not many students give back interaction to the teacher. Where the teacher still plays a major role in the delivery of learning material, this means that the interaction that occurs is still in one direction, namely the interaction between teacher to student, and does not get much response from students to teachers.

This causes student activity to be distracted by other things. Then, this can also cause students' understanding of the subject matter to be uneven and low student learning outcomes in Mathematics. So, it is not only students who feel the impact of the inability of classroom management by the teacher, even the teachers themselves will feel the impact of not implementing management in the classroom, namely in the form of difficulty achieving the objectives of learning mathematics.

To make a meaningful learning process, the students' activity is needed on the learning process. According to Asmani (2015: 60), the activity is defined as on the learning process, the teacher should create various situation so the students are active to ask, question, and convey the idea. Learning is an active process from the learner to build the knowledge. It is not a passive process that is only accept the teacher's lecturing about the knowledge. If the learning does not give a chance for the students to get involved actively, so the learning contradicts the nature of learning.

The importance of student activeness is explained by Zayyin (2017: 13) that the activeness of students during the teaching and learning process is an indicator of the desire or motivation of students to learn. Student activity is important because sometimes the teacher emphasizes the cognitive aspects, emphasizing the mental abilities learned so that it only focuses on understanding the material of knowledge. Student activeness in learning is an important and fundamental issue that must be understood, realized and developed by every teacher in the learning process. (Ramlah, Firmansyah, \& 
Zubair, 2015). According to Wibowo (2016: 129) there are several efforts that teachers can make in developing student learning activeness in subjects by increasing student interest, arousing student motivation, and using media in learning.

Uno and Mohamad (2014: 76) stated some characteristics of active learning as follows: (1) student-cantered learning; (2) the learning related to real life; (3) the learning stimulates students for high order thinking; (4) the learning serves the different styles of students' learning; (5) the learning stimulates students to interact multidirectional; (6) the learning uses the environment as a media or learning source; (7) the learning centres on the students; (8) Structuring the learning environment makes it easier for students to carry out learning activities; (9) The teacher monitors the students' learning process; (10) The teacher provides feedback on the children's work.

Thus, in the teaching-learning process, a teacher is not only required to have knowledge to impart to students. Teachers are required to have the ability to manage the class both, physically and nonphysically in terms of class members (students in the class). When the teacher can manage the class, it will create a conducive classroom atmosphere that will supports the activeness and effectiveness in a learning process itself.

From the description above, the authors are interested in knowing about "The Analysis of Class Management Ability to Improve Students' Activity on Mathematics Learning Process at Grade 8 SMP Swasta PAB 2 Helvetia".

\section{METHOD}

This research used qualitative research method with phenomenology approach, which the researcher directly observed the phenomenon happened on the field naturally. This research was conducted for two months on academic year 2018-2019 at SMP Swasta PAB 2 Helvetia. The research subject was two Mathematics teachers who taught at grade 8-1 and 8-5 and also the students of grade 81 which consisted of thirty-seven students and 8-5 which consisted of forty students.

Furthermore, the researcher chose a student from each class as the representative of grade 8-1 and 8-5 to be interviewed. While the research object was the class management ability which was done by the teachers in order to improve students' activity on Mathematics learning process at grade 8 SMP Swasta PAB 2 Helvetia.

The data collection procedure was carried out by the researcher as follows: (1) determining the research subject; (2) observing; (3) interview; (4) documenting; (5) data triangulation. While, student activities were analysed by researchers through: (1) Visual activities; (2) Oral activities; (3) listening 
activities; (4) Writing activities; (5) Drawing activities; (6) Motor Activities; (7) Mental activity and (8) Emotional activity.

Meanwhile, the class management is analysed by the researcher as follow: (1) Physical, which included the arrangement of students in learning, study rooms, and class furniture; and (2) Non-physical, which included aspects of students' interaction with other students, students and teachers, and the classroom and school environment, before, during, and after learning. And the class management problems analysed by the researcher were: (1) The individual problems consisting of attention getting behaviours, power seeking behaviours, hopelessness; and (2) The group problems which consists of two problems, namely the problem of racial sentiment and the problem of excessive group reactions.

\section{RESULTS AND DISCUSSIONS}

1. The students' Activity on Mathematics Learning Process at Grade 8 SMP Swasta PAB 2 Helvetia

Based on the detail of students' activity that had been explained on research methodology section, it can be seen that the proportion of students' activity from the learning process that had been set, namely visual activities, oral activities, listening activities, writing activities, drawing activities, motor activities, mental activities and emotional activities. As for the percentage recapitulation of student's activity level on the learning process that can be seen on the table below:

Table 1. The Percentage recapitulation of students' activity at grade 8-1.

\begin{tabular}{clc}
$\begin{array}{c}\text { The Students' Activity } \\
\text { Category }\end{array}$ & Percentage (\%) & $\begin{array}{c}\text { The Students' Activity Level } \\
\text { Quality }\end{array}$ \\
\hline Visual Activities & 66,22 & High \\
Oral Activities & 52,70 & High \\
Listening Activities & 73,65 & High \\
Writing Activities & 73,65 & High \\
Drawing Activities & 0 & Low \\
Motor Activities & 0 & Low \\
Mental Activities & 52,70 & High \\
Emotional Activities & 54,05 & High \\
\hline
\end{tabular}

From table 1, it can be seen that the average proportion of students' activity on Mathematics learning process at grade 8-1 is (1) Visual activities was $66.22 \%$ classified as high level; (2) Oral 
activities was $52.70 \%$ classified as high level; (3) Listening activities was 73.65\% classified as high level; (4) Writing activities was $73.65 \%$ classified as high level; (5) Drawing Activities was 0\% classified as low level; (6) Motor activities was 0\% classified as low level; (7) Mental activities was 52.70\% classified as high level; (8) Emotional activities was $54.05 \%$ classified as high level. From the data, it can be seen that the students' activity level at grade 8-1 SMP Swasta PAB 2 Helvetia was the lowest in drawing and motor activities.

Furthermore, the researcher discussed about the percentage recapitulation of student's activity level on the learning process that can be seen on the table below:

Table 2. The Percentage recapitulation of students' activity at grade 8-5.

\begin{tabular}{clcc}
\hline $\begin{array}{c}\text { The Students' Activity } \\
\text { Category }\end{array}$ & Percentage & $\begin{array}{c}\text { The Students' } \\
\text { Level Quality }\end{array}$ & Activity \\
\hline Visual Activities & 42.50 & Low & Low \\
Oral Activities & 30.63 & Low & \\
Listening Activities & 41.25 & Low \\
Writing Activities & 46.88 & Low \\
Drawing Activities & 0 & Low \\
Motor Activities & 0 & Low & \\
Mental Activities & 33.75 & Low & \\
Emotional Activities & 28.75 & & \\
\hline
\end{tabular}

From table 2, it can be seen that the average proportion of students' activity on Mathematics learning process at grade 8-5 is (1) Visual activities was $42.50 \%$ classified as low level; (2) Oral activities was $30.63 \%$ classified as low level; (3) Listening activities was $41.25 \%$ classified as low level; (4) Writing activities was $46.88 \%$ classified as low level; (5) Drawing activities was 0\% classified as low level; (6) Motor activities was 0\% classified as low level; (7) Mental activities was33.75\% classified as low level; (8) Emotional activities was $28.75 \%$ classified as low level. From the data, it can be seen that the students' activity level at grade 8-5SMP Swasta PAB 2 Helvetia was still low in every aspect.

2. The Class Management on Mathematics Learning Process at Grade 8 SMP Swasta PAB 2 Helvetia

Based on the observation and is supported by the interview, the researcher found that the physical management of grade 8-1 had been fulfilled. The condition of grade 8-1 itself had been good, the main furniture such as tables and chairs in a very good condition. Even though, there were some complements 
that had not been fulfilled, such as photos of the president, vice president and Pancasila. However, this did not interfere with the learning process in the classroom.

The teacher of G-1 had asked the students to clean the classroom before beginning the learning process. The teacher had tried to manage the class well, like setting the students' seat if it was needed. It was proved that from the observation, the researcher saw the teacher of G-1 asked the students to move the students' seat to the front if they felt difficult to look at to the whiteboard.

Grade 8-5 classroom was on the second floor, and unfortunately this class was on the side of the road. So, the vehicle sound was often heard inside the classroom. The teacher of G-2 did not respond the noise in the class, it made the class more unconducive. The teacher of G-2 chose to sit in the chair by asking the students to be calm down.

The students' calmness just happened when the teacher came to the student's table and checked the students'-work. After that, the class returned back to unconducive situation. While the researcher observed grade 8-5, the class was often in a dirty situation. It was understandable when the researcher came into the class in the last of learning process. But even though Mathematics was begun in the beginning day, the class was full by dust from the students' shoes. The G-2 teacher did not care about this situation. So that, the students kept beginning the learning process inside the dirty class.

While, for non-physical class management, the researcher found that the good physical class management was done by the G-1 teacher at grade 8-1 was time discipline to begin the lesson. As long as the researcher observed inside the class, the G-1 teacher often came into the class on time. Moreover, the G-1 teacher was able to master and gave the material to the students well. The learning material was given systematically and in detail.

In the class, the G-1 teacher tried to keep the class situation concussively by discipline students who began to interfere in the learning process. The teacher was active to motivate students to be brave asking and answering questions by not focusing on the correct or incorrect answers. The G-1 teacher also did not forget to evaluate the students. Moreover, it could train the students, the evaluation that was given by the teacher could be used as the indicator for students' learning achievement. It was just that the teacher did not build the interaction among students through directed discussions. And also, learning sources was not used on the learning process, made some students felt boring and sleepy.

The non-physical class management that was done by the G-2 teacher as Math teacher at grade 85 was the teacher began the lesson on time. It was one way to discipline the students about the time by practicing it. The G-2 teacher used to evaluate the students in the closing of lesson to assess the students' ability and trained them to complete various Math word problems.

JMME Halaman 97-109 
The G-2 teacher was able to master the learning material well, it was seen from how the teacher responded the students' questions. The learning material was given systematically that could help the students to relate one learning material to others. Through this, the students could construct their idea when they completed some tasks. It was only that the interaction process made between the teacher and the students ran less effective. It was showed through the feedback which was not complete from the students. The learning process did not involve the students thoroughly. The G-2 teacher just focused on explaining the lesson and paying less attention to make sure whether the students focused on the teacher's explanation or not.

However, the G-2 teacher had done the effort to improve the students' activity. By giving the chance to the students to come in front of the class to answer the question on the whiteboard and promised them to give the score as a reward. Grade 8-5 students themselves admitted that they are encouraged enough to get the score.

3. The Problems on the Class Management on Mathematics Learning Process at Grade VIII SMP Swasta PAB 2 Helvetia

The problems of class a management were classified into two categories, namely individual problems and group problems. Based on the observation and the interview that had been done to the teacher, the group problems did not occur on Mathematics learning process at grade 8-1 and 8-5. It was caused by the race, religion, and ethnicity that was almost completely same, made the group problems did not occur on Mathematics learning process. In addition, the interaction among the students which was not constructed yet by Math teachers in both of the classes, caused the gap among the groups did not happen yet.

For the individual groups which were reviewed from attention getting behaviours aspect, the researcher found that the students who showed an attitude such as did various acts on purpose to get the attention to ruin the class rules. That's why, the G-1 teacher explained that the teacher had to be able to direct the students' attitude to stay in line with the learning context. However, otherwise, it was explained by the G-2 teacher that he considered the students' attitude as the students' activity. Through the teachers' direction and guidance, this attitude was able to make the students active in having the learning process.

Then, for power seeking behaviours aspect which the students had the attitude to feel powerful so that the teacher had to be ready to overcome various of students' attitude and character. The teacher had to prepare the accurate way to overcome it. Based on the interview result, the G-2 teacher chose to do an approach religiously to overcome the students who felt powerful. 
Furthermore, for hopelessness aspect that the researcher got form the interview result, it showed that the G-1 teacher said that to overcome the students with such attitude above, it was better if the teacher was able to guide the students thoroughly. The teacher also had to be able to communicate it with their parents. The G-2 teacher considered that the students' attitude and character was the part of challenge that the teacher got in teaching them. In line with the G-1 teacher, the G-2 teacher considered that this attitude was the students' passive act that needed the extra guide.

\section{CONCLUSIONS}

Based on the research result that was done, then the researcher concluded that the students' activity on Mathematics learning process consisted of eight activities namely visual activities, oral activities, listening activities, writing activities, drawing activities, motor activities, mental activities and emotional activities with different percentages on each class.

Percentage in grade 8-1 showed that the students' visual activities aspect was $66.22 \%$ classified as high level, Oral activities was $52.70 \%$ classified as high level, listening activities was $73.65 \%$ classified as high level, writing activities was 73.65\% classified as high level, Drawing Activities was $0 \%$ classified as low level, Motor activities was $0 \%$ classified as low level, Mental activities was $52.70 \%$ classified as high level, and Emotional activities was 54.05\% classified as high level.

While in grade 8-5, the percentage showed that Visual activities was $42.50 \%$ classified as low level, Oral activities was $30.63 \%$ classified as low level, listening activities was $41.25 \%$ classified as low level, writing activities was $46.88 \%$ classified as low level, drawing activities was $0 \%$ classified as low level, Motor activities was $0 \%$ classified as low level, Mental activities was $33.75 \%$ classified as low level and Emotional activities was $28.75 \%$ classified as low level.

The class management that had been done by the teachers was divided into two aspects, namely physical aspect such as the setting of students' seat, class cleanliness, the students' comfort, and also completeness of facilities and infrastructure. And non-physical aspect such as the interaction among students, the students and the teachers, and the class and school environment, before, during, and after the learning process. The problems that were faced by the teachers in managing the class were divided into two categories, namely the individual problems and the group problems.

In fact, when the researcher did the observation, the researcher did not find any group problems at class. It was caused by the domination of ethnics, race, and religion at the class and also there was less interaction among students. So that the gap between groups at class did not occur. The individual problems that were faced by the teachers in managing the class, namely the students' attitude in seeking 
attention, the students who felt powerful (seeking attention behaviours), and the students' who felt hopeless (hopelessness).

\section{REFERENCES}

Asmani \& Jamal, M. (2014). 7 Tips Aplikasi PAKEM. Yogyakarta: DIVA Press.

Barnawi \& Arifin, M. (2015). Micro Teaching: Teori dan Praktik Pengajaran yang Efektif dan Kreatif. Yogyakarta: Ar-Ruzz media.

Nagler, K. S. (2016). Effective Classroom-Management \& Positive Teaching. Canadian Center of Science and Education, 9(1). 163-172. Diambil dari http://dx.doi.org/10.5539/elt.v9n1p163

Nurani, U., Sulistiani, I.R., \& Dewi M.S. (2020). Pengelolaan Kelas Guru Dalam Pembelajaran $\begin{array}{lllll}\text { Matematika. } & \text { JPMI, } & \text { 143-147. } & \text { Diambil }\end{array}$ http://www.riset.unisma.ac.id/index.php/JPMI/article/download/7701/6213

Perangin Angin. (2018). Manajemen Kelas Buku Pegangan bagi Calon Tenaga Guru dan Kependidikan. Medan: Fakultas Ilmu Pendidikan Universitas Negeri Medan

Prameswari, S.J., \& Budiyanto, C. (2018) The Development of the Effective Learning Environment by Creating an Effective Teaching in the Classroom. Indonesian Journal of Informatis Education, 1(1), 79-86. DOI:10.20961/ijie.v1i1.11960.

Ramlah, R., Firmansyah, D., \& Zubair, H. (2014). Pengaruh Gaya Belajar dan Keaktifan Siswa Terhadap Prestasi Belajar Matematika (Survey Pada SMP Negeri di Kecamatan Klari Kabupaten Karawang). Jurnal Ilmiah Solusi, 1(3), 68-75. Diambil dari https://journal.unsika.ac.id/index.php/solusi/article/view/59

Rohani, A. (2010). Pengelolaan Pengajaran (Sebuah Pengantar Menuju Guru Profesional). Jakarta: PT Rineka Cipta.

Rusydie, S. (2015). Prinsip-Prinsip Manajemen Kelas. Yogyakarta: DIVA Press.

Suherman, Y \& Nurjanah. (2013). Manajemen Kelas untuk Efektivitas Pembelajaran. Bandung: CV Wahana Iptek Bandung.

Syatra, N. (2013). Desain Relasi Efektif Guru dan Murid. Yogyakarta: Bukubiru. 
Uno, H. \& Mohamad, N. (2014). Belajar dengan Pendekatan PAILKEM: Pembelajaran Aktif, Inovatif, Lingkungan, Kreatif, Efektif, Menarik. Jakarta: Bumi Aksara.

Wibowo, N. (2016). Upaya Peningkatan Keaktifan Siswa Melalui Pembelajaran Berdasarkan Gaya Belajar di SMK Negeri 1 Saptosari. Jurnal Electronics, Informatics, and Vocational Education (ELINVO), 1(2), 128-139. Diambil dari https://journal.uny.ac.id/index.php/\%20elinvo/article/viewFile/10621/8996

Zayyiin, N. R. A. (2017). Meningkatkan Keaktifan dan Hasil Belajar Matematika dengan Model Pembelajaran Kooperatif Tipe Group Investigation. UNION: Jurnal Pendidikan Matematik, 5(1), 11-20. Diambil dari https://www.researchgate.net/publication/328364388_MENINGKATKAN_KEAKTIFAN_DA N_HASIL_BELAJAR_MATEMATIKA_DENGAN_MODEL_PEMBELAJARAN_KOOPERA TIF_TIPE_GROUP_INVESTIGATION 